\title{
The Decline of Village Safety and Supply Forest Land Use in Mizoram: A Case Study of Kolasib District.
}

\author{
Dr. Rintluanga Pachuau ${ }^{1}$ \\ ${ }^{l}$ Associate Professor \\ Department of Geography and Resource Management \\ School of Earth Sciences, Mizoram University Aizawl, Mizoram. P.O. Box - 190.
}

\begin{abstract}
Mizoram is one of the North Eastern states of India governed by tropical climate subjected by monsoon rains. This factor led to luxuriant growth of vegetation earlier in the past and still remain one of biodiversity hotspots of India. The state is dominated by tribal population, who take maximum advantage of the forest resources since their first settlement in the region. Despite the on-going developmental process socially and infrastructurally, safety of village dependence on forest supply and subjected changing pattern of land use are still govern by the utilization of resources of the local people. The paper tries to assess the declining trend of the village safety in terms of protection and security and supply of forest resources as well as changing pattern of land use. The paper is based on a comprehensive field survey conducted in a systematic manner. So much so that the paper is able to provide appropriate conclusion for future planning.
\end{abstract}

Keywords: Village safety and supply forest, Mauhak, Accessibility, Tradition, Community.

\section{Introduction}

The growing concern of climate change and its negative consequences had made the people from all walks of life to pay more attention on forest and its ecosystem, their services and function for the future of the planet earth. The realization of tangible and intangible services of forest for mankind and the world climatic condition by different section of the world community had called for the urgency of sustainable management of forest to mitigate the on-going process of climate change[1]. The remaining forests of the world are largely confined in the tropical regions[2] harboring a rich flora and fauna. Meanwhile, these world remaining forests are under intense pressure to meet the demand of the ever increasing world population, as such deforestation rate is high in this region. The forest cover and land use changes are mainly anthropogenic in tropical countries and are being increasingly recognized as critical factors influencing global environmental changes[3] [4]. However, tropical countries are less developed and different tribal communities are largely concentrated in this region. Majority of these tribal communities depends solely on forest for their livelihood. They have a symbiotic relationship with forest since a long time a go.

India is one of the tropical countries where two of the world's important biological diversity hotspot region is located. One of its biodiversity hotspot is found in the North Eastern Region (NER) of India. The NER comprised of seven states of the Indian union. Majority of the population belongs to the tribal community. Forest had been their source of livelihood and conversion of forested land to shifting cultivation is common in this eastern himalyan region [5] [6] [7] [8] [9]. It is part of their culture and history for the people of this region.

The state of Mizoram is one of the seven states in the NER. The people of Mizoram have a long history and culture of clearing forest for jhum purposes while maintaining forest conservation. However, in due course of time, it is difficult for the mizo community to continue their tradition of conservation due to socio-economic pressure. The tradition of allotting a portion of forest in the vicinity of the village, called Village Safety and Supply Forest, has become difficult though The Mizoram Forest Act 1955 demand every village leaders to constitute the village safety and supply forest in their own jurisdiction. The present paper analyze changes in the village safety and supply forest at district level. Kolasib district, located in the northern most part of the state is selected for the present study.

Kolasib district is situated in the northern most part of Mizoram between $24^{\circ} 31^{\prime} 14.43$ " and $23^{\circ} 51^{\prime}$ 15.13" N latitudes and $92^{\circ} 31^{\prime} 46.92^{\prime \prime}$ and $92^{\circ} 54^{\prime} 11.40 "$ E longitudes. The district falls in the Survey of India Topo sheet Nos. 83D/11, 83D/12, 83D/14, 83D/15, 83D/16, 84A/9 and 84A/13. It is bounded by Cachar district of Assam on the north and Aizawl District on the south and east; and on the west by Cachar district and Mamit district. The total extent of the district is 138,251 ha and population 65,960 , showing a density of 47.8 persons per sq.km as against the density of the Mizoram state -42 persons per sq.km. 


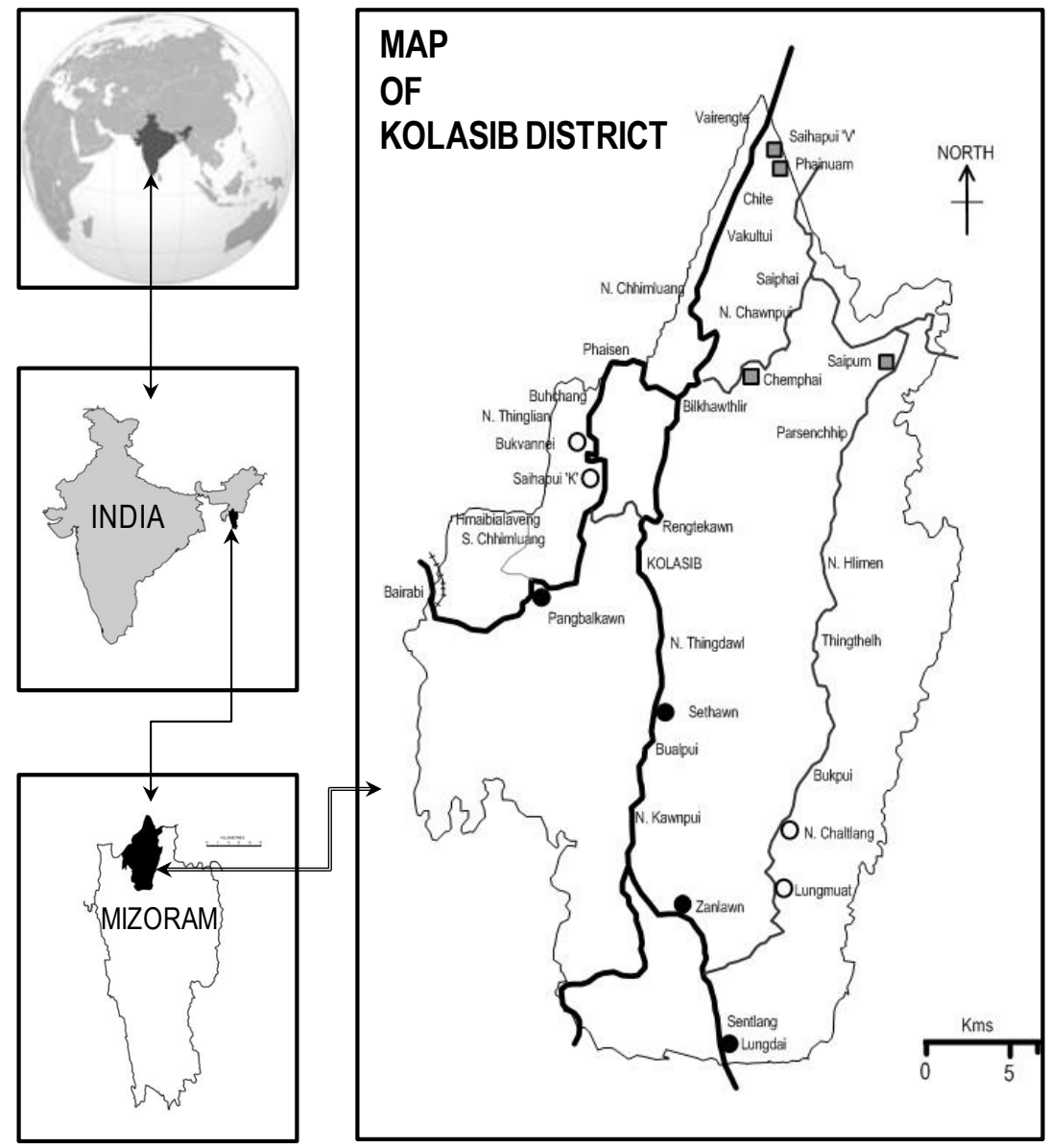

Figure 1: Location Map showing Sample Villages

The forest cover type in the district can be mainly identified as tropical wet evergreen forest and tropical semi evergreen forest associated with moist deciduous forest (Table: 1)

Table 1: Forest Type of Kolasib district.

\begin{tabular}{|l|l|}
\hline Forest Type & Area (\%) \\
\hline Evergreen & 9.70 \\
\hline Semi Evergreen & 23.09 \\
\hline Moist deciduous with bamboo brake & 47.55 \\
\hline Other Land use & 19.66 \\
\hline
\end{tabular}

Source: Sample Survey \& MIRSAC Report[10]

\section{Theory and Concept}

The Mizos, in their history and culture have a tradition of respecting nature. Conservation of forest is part of the culture while forest and its product were their resort for livelihood. A large tract of wood forest and bamboo forest called 'Mauhak' was conserve in the vicinity of the village to protect the village from enemies and forest fire, while it is also used to ensure the continued water supply and to meet the needs of village community for various purposes like housing materials. It is well protected and manages on a sustainable basis. However, the advances in society and economy coupled with administration changes (from traditional village chief to modern democratic system) had witness the beginning of the deteriorating condition of village safety and supply forest[11]. It was realized that it is imperatives to continue allocating a plot of forest land nearby the village. Therefore, The Mizoram Forest Act 1955 was passed at the time of District Council Administration to enforce the reserve of three classes of Village Forest in all the village of Mizoram, namely - Village Safety Reserve, Village supply Reserve and Protected Forest Reserve[12].

Village Safety Reserve is reserve for the protection against fire and constituted in the interest of health and water supply. No one shall utilize for any purpose, any portion of land inside this reserve and no trees shall be cut in this reserve except with the permission of the State Government. The Village Council may dispose of any dead trees in the manner it considers most beneficial for the Village. Village Supply Reserve is reserve for the supply of the needs of the village. Any person resident in the Village may cut trees and bamboos from this 
reserve for his household needs. Protected Forest Reserve is reserved for Protection of valuable forest from destruction for the interest of the village communities. No one shall utilize for any purpose any portion of Land inside this protected Forest Reserve and no tree, shall be cut in the Protected Forest Reserve except with the permission of the State Government. Any person doing anything in contravention of any of the provision of this section shall be punishable with a fine not exceeding Rs. 50/-

The Boundary of the village Forest Reserve being properly demarcated shall be marked by sign posts and stone pillars. The record of the boundaries, stating places where such posts or marks are made shall be kept by the President of the village council committee. A copy signed by the President shall be submitted to the State Government.

\section{Material and Method}

Kolasib district is the only district, which have a railway connection and interstate road link. The assumption is that accessibility will play a crucial role in the socio-economic development of the district and levels of exploitation of natural resources. Twelve villages out of forty villages were stratified in to three category base on bus frequency and nearness to the market.

Table: 2 Stratification of villages in terms of Accessibility.

\begin{tabular}{|l|l|l|l|l|}
\hline Characteristics & Very Accessible & $\begin{array}{l}\text { Medium } \\
\text { Accessible }\end{array}$ & $\begin{array}{l}\text { Relatively In- } \\
\text { accessible }\end{array}$ & Whole District \\
\hline No. of villages & 12 & 8 & 20 & 40 \\
\hline Average household/village & 249 & 142 & 109 & 158 \\
\hline Average population/village & 1161 & 748 & 502 & 740 \\
\hline Average distance from town & 21 & 30 & 28 & \\
\hline Average Bus frequency & 11 & 4 & 2 & \\
\hline
\end{tabular}

After stratification, four villages from each stratum were randomly selected for sample survey representing about 30 percent of the village in the district. It may be regarded as the results and findings are reasonable enough to draw a conclusion for the study area. The villages in strata-1 like Sethawn/Thingdawl and Sentlang/Lungdai were club together as they were under one jurisdiction of the village council committee respectively.

Table: 3. List of randomly selected twelve villages with their toposheet references

\begin{tabular}{|l|l|c|}
\hline Strata Code & Name of Villages & Toposheet references \\
\hline 1 & Sethawn/N. Thingdawl & $83 \mathrm{D} / 12,2 \mathrm{C}$ \\
\hline 1 & Sentlang/Lungdai & $84 \mathrm{~A} / 9,2 \mathrm{~A}$ \\
\hline 1 & Pangbalkawn & $83 \mathrm{D} / 12,1 \mathrm{~B}$ \\
\hline 1 & Zanlawn & $84 \mathrm{~A} / 9,1 \mathrm{C}$ \\
\hline 2 & Bukvannei & $83 \mathrm{D} / 11,3 \mathrm{~B}$ \\
\hline 2 & Saihapui 'K' & $83 \mathrm{D} / 11,3 \mathrm{~B}$ \\
\hline 2 & Lungmuat & $84 \mathrm{~A} / 13,1 \mathrm{~A}$ \\
\hline 2 & N. Chaltlang & $83 \mathrm{D} / 16,3 \mathrm{~A}$ \\
\hline 3 & Phainuam & $83 \mathrm{D} / 5,3 \mathrm{~B}$ \\
\hline 3 & Chemphai & $83 \mathrm{D} / 15,2 \mathrm{~A} \& 3 \mathrm{~A}$ \\
\hline 3 & Saihapui 'V' & $83 \mathrm{D} / 15,2 \mathrm{~A}$ \\
\hline 3 & Saipum & $83 \mathrm{D} / 15,2 \mathrm{~B}$ \\
\hline
\end{tabular}

The survey tools used consisted of interaction with the village community, participatory appraisal, structured questionnaire and field verification/quality control. The randomly selected sample villages were assessed using the aforementioned survey tools for two dates (i.e 1997 \& 2007) to estimate changes in socioeconomic and forest condition. Data were collected on socio-economic attributes, land use pattern and trend of the observed change for the aforesaid parameters with possible causes.

The satellite image of study area by Indian Remote Sensing Satellite IRS-1D LISS-III of 2005 procured from NRSA Data centre Hyderabad was used for classification and change assessment of land use land cover in the study area.

\section{Discussion}

The forest in the study area was classified into six categories, namely-Dense Forest, Open Forest, Bamboo Dominant, Teak Plantation, Safety and Supply Forest and Other Forest. It is regarded as necessary to assess other forest land use to compare with the safety and supply forest to know which path of changes is followed by different category of forest land use in their respective stratum. The following table is presented to know the status of various forest land use in sampled villages. It is to be noted that 1997 was taken as the base year for calculating changes in percentage. 
The Decline of Village Safety and Supply Forest Land Use in Mizoram: A Case Study of .....

Table: 4. Changes in various forest land use (in Ha) (1997 and 2007)

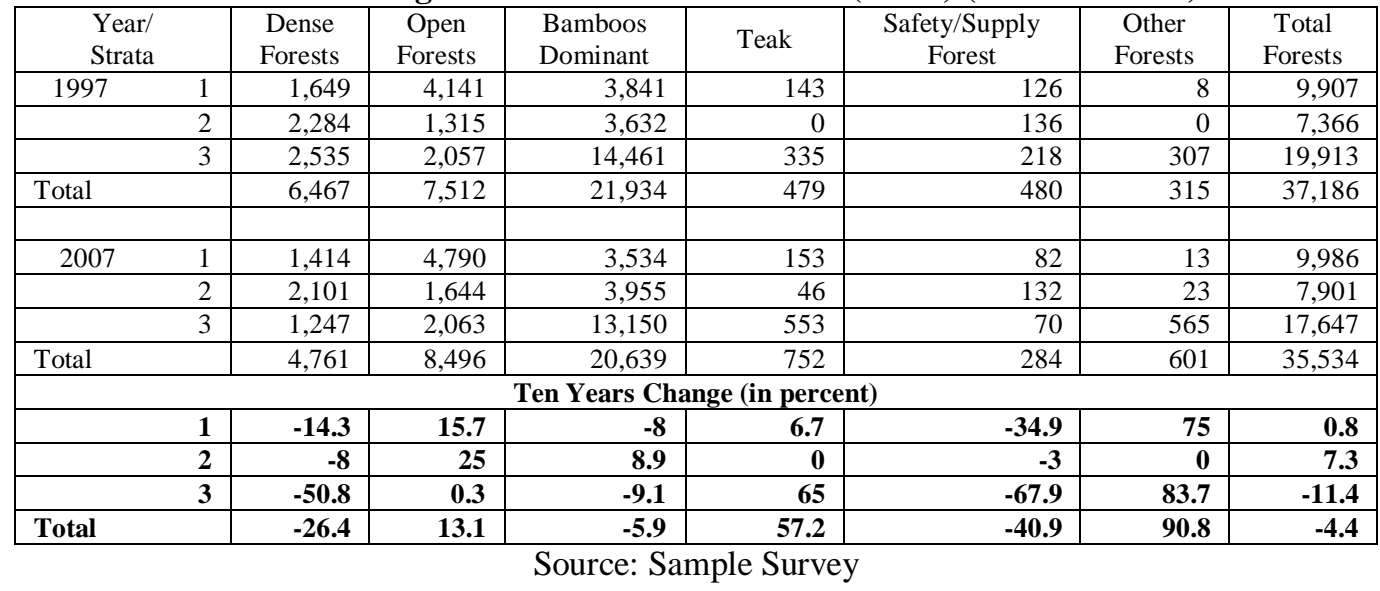

There is a significant decrease in dense forest and safety and supply forest in all the strata while open forest and teak plantation is increasing in all the strata may be at the cost of dense forest. The in-accessible villages witness the largest decrease in dense forest and village safety/supply forest. The open forest is increasing in very accessible and medium accessible village, the teak plantation is also increase in very accessible village, at the same time, it is dramatically increase in in-accessible village. The factor of accessibility closely follows the path of changes in various forest land use.

Table: 5. Changes in Population, Household and Safety/Supply Forest

\begin{tabular}{|c|c|c|c|}
\hline Year/Strata & Household & Population & Safety/Supply Forest (ha) \\
\hline 1997 & 1230 & 5910 & 126 \\
\hline 2 & 490 & 2700 & 136 \\
\hline 3 & 427 & 2260 & 218 \\
\hline Total & 2147 & 10870 & 480 \\
\hline 2007 & 1563 & 7308 & 82 \\
\hline 2 & 544 & 3060 & 132 \\
\hline 3 & 778 & 4726 & 70 \\
\hline Total & 2885 & 15094 & 284 \\
\hline \multicolumn{4}{|c|}{ Change (\%) } \\
\hline 1 & 27.1 & 24 & -34.9 \\
\hline 2 & 11 & 13.3 & -3 \\
\hline 3 & 82.2 & 109 & -67.9 \\
\hline Total & 34.4 & 39 & -40.9 \\
\hline
\end{tabular}

Source: Sample Survey

Table -5 indicates that the percentage change in population and household is closely related to the percentage changes in village safety/supply forest. As expected, sample villages in accessible area witness a higher increase in population and household. The medium accessible villages follow the decadal increase in population and household. There is almost double increase in inaccessible villages. The reason for this abmormal increase in population and household is that there is an unexpected migration of the Reang community from outside and within the state. Forest is exploited extensively for their livelihood and makeshift house purposes [13]. The very accessible villages have a decadal increase of household and a population at 27.1 and 24\%; while the safety/supply forest decreased at $34.9 \%$ within a decade. The medium accessible villages have the least in household and population growth at $11 \%$ and $13.3 \%$. The decrease of safety/supply forest is also minimal at $3 \%$. The villages in the inaccessible area have the largest household and population growth at $82.2 \%$ and $109 \%$ respectively due to un-expected migration. This is reflected in the loss of safety/supply forest at $-67.9 \%$ within a decade.

\section{Conclusion}

The result and discussion made based on the sample survey show that accessibility plays a crucial role in forest land use change, especially on village safety/supply forest. Those villages in easily accessible areas are able to continue the tradition of conserving the safety/supply forest even with a high population pressure. There is a different findings in the village of remote areas-forests are under intense pressure due to socio-economic development. It is not possible to maintain the tradition of conserving a plot of land for the sake of safety/supply forest. There are some villages in remote areas where the safety/supply forest does not exist at all. The overall 
results for the district shows that the safety/supply forest is decreasing at $-40.9 \%$. The most unwelcome and unfortunate finding is that the tradition of keeping safety/supply forest for the sake of village community is declining in the minds of the people. Therefore, two things should be kept in mind while planning for the development of villages-accessibility seems to be the bottleneck for the development of villages and the people should be aware of the value of local tradition and culture which could play a pivotal role for sustainable management of the environment, that will be benefit the local community and beyond.

\section{References}

[1]. David Kaimowitz and Arild Angelsen, Economic Models of Deforestation: A review, CFOR, Indonesia, 1998.

[2]. Myers, "Tropical Deforestation: Rates and Patterns". (The Causes of Tropical Deforestation, in Brown and Pearce (eds), UCLP), pp. 27-40., 1994

[3]. Helmut J. Geist and Eric F, Lambin, "Proximate Causes and Underlying Driving Forces of Tropical Deforestation". Biosicience, Feb 2002, Vol. 52(2), ProQuest Biology Journal, pp.143, 2002.

[4]. Nagendra, H., Munroe, D.K. and Southworth, J., "From Pattern to Process: Landscape Fragmentation and the Aalysis of Land Use / Land Cover Change.”. Agric. Ecosyst. Environ., Vol. 101, pp. 111-115, 2004

[5]. Singh, J.S., Pandey, U, and Tiwari, A.K., "Man and Forests: A Central Himalayan Case Study", Ambio, Vol. 13. Pp. 80-87, 1984.

[6]. Rai, S.C., Sharma, E. and Sundriyal, R.C., "Conservation in the Sikkim Himalaya: Traditional Knowledge and Lansd Use of the Malay Watershed", Environmental Conservation, Vol. 21, pp. 30-34. 1994.

[7]. P.S. Ramakrishna, A.N. Purohit, K.G. Saxena and K.S. Rao, Himalayan Environment and Sustainable Development, Indian National Science Academy Diamond Jubilee Publication, New Delhi., 1994

[8]. Schweik, C.M., Adhikari, K. and Pandit, K.N, "Land Cover Change and Forest Institutions: A comparision of two Sub-basins in the Southern Shivalik Hills of Nepal'. Mountain research and Development, Vol. 17, pp. 99-116, 1997.

[9]. Sen, K.K., Senwal, R.L., Rana, U., Nautiyal, S., Maikhuri, R.K., Rao, K.S. and Saxena, K.G., "Patterns and Implications of Land Use/ Cover Change: A Case Study in Pranmati Watershed'. Mountain Research and Development, Garhwal Himalaya, India, Vol. 22, pp. 56-62. 2002.

[10]. State Remote Sensing Centre, Natural Resource Mapping of Mizoram using Remote Sensing and GIS, Kolasib District (A Project Report), Sicence, Technology and Environment, Planning Department, Aizawl, Mizoram, 2005.

[11]. Singh, K.D., Sinha, B. and Lalchamreia, H., Report on 'Survey Technique and Planning for Conservation and Sustaianable Use of Biodiversity in Mizoram' (Unpublished), 2010.

[12]. http://lad.mizoram.gov.in/page/forest-act-1955.html (Access on 8th November, 2013).

[13]. Lalchamreia, H. and Rintluanga, Pachuau, "Land Use Land Cover Change in Tuichhuahen Watershed, Kolasib District of Mizoram”, Geographic, Vol. 5, July, 2010, pp.15-20, Geography Association of Mizoram, Aizawl, Mizoram. 2010. 